\title{
办好样板田 促进农业科学大发展
}

赵明

目前, 一个以样板田为中心、以专业科 学技术队伍为骨干、以萧众科学实驗活动为 基础的大規模的农业科学实驗革命运动，正 在全国范围內形成和发展。

1962 年 9 月, 中国共产党八届十中全会 指出: “要加強科学技术的研究, 特別是要 注意对农业科学技术的研究。”1963 年 5 月, 毛泽东同志提出了 “阶段斗爭、生产斗爭和 科学实驗是建設社会主义強大国家的三項伟 大革命运动”的号召。根据党中央和毛泽东 同志的指示, 各地党委都在抓阶级斗爭、生 产斗爭的同时, 加強了对科学实验, 特別是 农业科学实驗的領导。广大农民鋷众通过社 会主义教育运动, 政治覚悟大大提高, 生产 热情空前高涨, 迫切要求实現技术革命, 进 一步改变生产面貌。他們积极学科学, 用科 学, 升开展科学实驗活动。許多农业科学技 术工作者积极响应党的号召, 紛粉下楼出 院、下乡上山, 到农村去长期䠘点。他們以 样板田为主要陣地, 同掱众科学实驗活动相 結合, 按照生产需要, 开展了农业科学研究 工作。

样板田是毛泽东思想指导下的产物, 是 多、快、好、省地发展农业生产、发展农业 科学、領导农业生产的重要途径。在生产
上，它是达到稳产高产、增产增收的重要手 段。在科学上, 它是密切联系实际、联系生 产、联系样众，为生产服务的重要途径; 是 总結农民經驗、推广科学研究成果、进行实 驗研究的重要陣地; 是农业科学实验革命运 动的重要环节。同时，它又是最受农民摹众 欢迎, 最易于为拲众接受的領导农业生产的 好方法; 是毛主席教导我們的一般号召和具 体指导相结合，领导和萑众相结合，突破一 点, 带动全局的領导方法的具体体現。

这个新生的事物，虽然大规模发展的时 間还不长，但是已經显示出它的巨大的生命 力。事实証明, 以領导干部、科学技术人員、 农民㨻众三結合; 实驗室、試驗場、农村基 点三結合; 試驗、示范、推广三結合, 这样 三个“三結合”为特色的样板田, 由于采用了 有效的技术措施，发揮了恽众生产积极性， 加強了农田基本建設，一般都获得显著增 产。在高产地区，它比一般农田增产二、三 成；在低产地区，增产的幅度更大，一般增 产三、五成甚至一倍以上; 就是在发生严重 自然災害的情况下，样板田收成也高于自然 条件相同的一般大田。样板田为堡众提供了 看得見、摸得到、学得会、信得过的 “活教 材”，从而带动了更大范围的增产。 
样板田冲破了洋框框、旧框框的束缚, 树立和发展了正确的研究思想、研究作风和 研究方法。

样板田的出现，为农业科学战线上贯彻 毛泽东同志的理论和实践相结合的光辉思 想，开辟了一条广阔的途径。在农村，有着 成千上万的基层领导干部、劳动模范、技术 能手和一批有成就的农民科学家。他们是实 际掌握农业生产技术的，指挥农业生产的。 我国农民几千年来，在同自然作斗爭的过程 中积累了大量的生产实践经验。这些经验本 身就包含了丰富的科学內容, 只要加以集 中、整理和总结, 是可以上升为光辉的科学 理论的。但是, 过去有不少农业科学研究工 作者, 却长期习惯于关起门来, 脫离生产具 体条件进行科学研究工作。这种做法, 不能 集中广大檴众的智慧，不能适应农业生产上 极其复杂多样的自然条件与社会条件，不能 迅速通过較大范围的实践来检验研究成果, 因而阻碍了农业科学技术的发展。样板田把 专业农业科学技术工作同农民堡众的生产斗 争和科学实验活动有机地结合起来了，使农 业科学研究工作者跳出了狭险的圈子，进入 了广阔的研究天地; 使农业科学实验的实践 扎根于农业生产斗爭的实践的土壤里，扎根 在广大农民学众的实践的土壤里，从而根深 叶茂, 壮健成长。

农业科学的研究课题, 除了少数基本理 论的研究课题以外，一般都应该根据农业生 产的需要，从农业生产的实践中来; 应该从 藩众的需要出发，以当前任务为主，同时也 不忽略基本理论的研究、基本资料积累等长 远发展的需要。

农业科学工作者，必须重视自己的研究 结果在生产中的运用和推广, 而不能把研究
结果写成论文就算了事。要把推广看成是研 究工作的继续, 看作认识自然规律的整个过 程中不可缺少的重要环节，通过推广来检 验、补充和发展已有结果。事实表明，研究 和推广是不可分割的。通过实验研究得出结 论, 仅仅是完成了实验研究的前一段, 郎从 物质到精神的飞跃; 更重要的一段，是精神 到物质的飞跃，郎是把研究结论回到生产实 践中去。样板田使实验研究和推广结合起来 了，使点、片、面结合起来了，形成了薭众 性的科学技术网，不仅促进了生产，而且发 展了科学，使科学为广大萦众所掌握。

开展以样板田为中心的农业科学实验, 能不能提高科学水平, 能不能促进科学大发 展呢？一个新生事物，在其开始时会遭到一. 些人怀疑，这是可以理解的。但是若将高产 和科学看作两件沒有联系的事物, 认为样板 田在生产上是高水平的，而在科学上的水本 是不高的，这显然是不符合辯証唯物主义的 覌点的。恩格斯說: “科学的发生和发展从 开始起便是由生产所决 定的。”农业科学来 源于农业生产实践，然后又反过来为农业生 产实践服务; 通过农业生产实践，又必将 进一步发展农业科学。凡是从实践中抽出 来, 又經过实践証明是正确的理論, 就是科 学。毛泽东同志教导我們: “真正的理論在 世界上只有一种，就是从客覌实际抽出来又 在客覌实际中得到了証明的理論, 没有任何 別的东西可以称得起我們所詊的理論。”事实 告诉我們, 通过样板田不是已經出了不少有 科学水平的理論嗎? 今后还必将出現更多更 好的成果。虽然样板田发展的时間不算长, 但已有很多事例說明了它正在把我国的农业 科学推向一个新的阶段。

首先是, 許多科学研究成果在样板田上 
經过检驗, 得到了充实和提高, 并且得到了 迅速的推广。例如: 种植綠肥、塑料薄膜育 䄯、菞剂处理消灭麦类黑穗、各种作物的良 种以及先进栽培技术等等, 都已在农业生产 上发揮了增产作用。

其次，通过样板田总結了不少农民荐众 的經驗，使之上升为理論。例如，陈永康、 崔竹松的水榴高产經驗总結等等。

第三, 在样板田上所进行的科学研究, 目的性很明确。样板田要求科学研究工作适 应不同地区的具体条件。科学技术工作者在 这里遇到了实驗室、試驗場所不具备的各种 复杂生动的情况, 由此得到了更丰富、更具 体的研究材料, 使研究成果更加充实。例 如, 在湖南部阳改良“鴨屎泥”的样板田里, 科学工作者經过反复实践, 摸到了鴨屎泥田 磷素轉化的一些規律, 先是找到了使用磷肥 防治水稳“坐秋”的办法, 进一步又发现种植 綠肥不仅可以活化土壤磷素，防治水稻 “坐 秋”, 而且可以提高土壤肥力, 改一季稻为 双季稻，获得了更高的产量。

第四，在样板田上研究解决生产实际問 題的过程中, 随着訩識的不断深化, 揭示了 更多客覌規律, 使結論更为可靠。例如, 我 国北方各地的一些农业科学技术工作者, 长 期在試驗場的肥力很高的田地上, 試驗了磷 肥的效果，曾得出“在石灰性土壤中使用 磷 肥无效”的錯誤結論。近几年来，又在各地 基点和样板田中广泛进行了試驗, 用事实推 翻了过去的論断。

此外，各地样板田广泛建立了田間档 案, 經过几年的系統記載后, 就可以掌握一 个地区生产发展的系統变革情况以及不同田 块的载培特点。这样就可以更多地发掘和更
好地理解我国农民长期积累的大量經驗，就 有可能更有目的地开展科学研究, 为再增产 开辟新的道路。上述这几方面都充分說明了 样板田是能够多、快、好、省地发展农业科 学技术的。

当然, 这并不是说其他的科学实验工作 是不重要的, 是可以忽略的。我们既要抓样 板田，也要抓专业的农业科学技术工作和农 民罯众的科学实验活动。当前, 所以把样板 田作为农业科学实验运动的主要环节, 目的 是为了带动整个农业科学实验运动。因此, 必须对当前和长远、室內和室外、这些学科 和那些学科、这些项目和那些项目, 做出全 面的穻善的安排。有些不宜全部拿到样板田 进行实验的, 但对当前或长远生产有重要意 义的研究课题，必须安排在试验场、实验室 坚持进行研究; 倘有少数研究工作，目前看 来目的性还不够明确，但只要有苗头，也应 当有适当的安排。总之，不可不顾条件，一 妻而起, 也不可只顾一头, 丢奔其他。

近年来, 我国成千上万的农业科学技术 工作者下乡䠝点，投身到阶級斗学、生产斗 爭、科学实驗三項伟大的革命运动中去。在斗 爭中，他們的思想感情逐漸起了变化。他們 提高了阶級覚悟，也提高了业务水本。实践 証明，以样板田为中心的农业科学实驗运 动，对于培养又红又专的农业科学技术工作 者也是有重大的作用的。

訆我們在毛泽东思想的指引下，在党的 正确領导下，积极投入到以阶級斗爭为綱、 以生产斗爭为中心的科学实 驗 革命 运动中 去, 为促进我国社会主义建设和农业科学的 大发展而奋斗! 